Research Article

Tariq Modood*

\title{
Intercultural Public Intellectual Engagement ${ }^{1}$
}

https://doi.org/10.1515/jcgs-2017-0004

\begin{abstract}
The article firstly examines the different conceptions of dialogue and reason within political theory, especially in the work of Rawls. Secondly we explore multicultural political theorists who have been motivated less by abstract reasoning by a sole reasoner or identical identity-less individuals and more by dialogue. For such multiculturalists, the principles of social justice are not known in advance or simply by reason, but are arrived at by conflict and learning, by dialogue and negotiation in circumstances of inequality and minority-claims making. In response to the multiculturalists, interculturalists allege that multiculturalism is too focused on the macro and the conflictual, and dialogue should be redirected to the micro and the cooperative. Although I welcome the interculturalists' focus on micro-relations, this does not require abandoning the idea of dialogue at the level of political controversies and public discourses. It is not an either-or choice because groups and intergroup problems exist in society and cannot be simply handled at a micro level of contact, interaction and sociability. The kind of macro-level dialogue that I am speaking of can also be understood as a form of public intellectual engagement that can contribute to societal dialogues.
\end{abstract}

Keywords: dialogue, multiculturalism, interculturalism, public intellectuals, political theory, reason

\section{Dialogue and Reason in Political Theory}

A good place to begin the topic of dialogue and the contribution of intellectuals, and especially of political theory, is with Socrates. Not only does he, as he appears in the works of his student Plato, take us to what may iconically represent the founding moment of western philosophy and political theory, he also takes us to the most basic meanings of the term "dialogue", namely, focused oral communication between at least two interlocutors or its portrayal as a literary genre. Socrates was famous for endlessly questioning individuals in the public square, the agora, and Plato wrote dialogues. Plato's dialogues take two forms. Most of the early dialogues, referred to as eristic, take the form of an interrogation. Socrates is portrayed engaged in a hostile series of questions aimed to show that his interlocutor, often a well-known "Sophist", does not know what he is talking about. ${ }^{2}$ Socrates sets out to destroy the argument of his interlocutor and to discredit him as either a teacher, a learned person, or an authority on wise conduct. These dialogues typically end in a breakdown with Socrates' opponent alleging that Socrates is constantly twisting his words for his own self-aggrandisement, so there is no point in carrying on. The other kind of dialogue, of which The Republic is the most famous example, is more like an interview and consists of a rational cooperation to discover the Truth.

1 This article is a reprint of Tariq Modood (2017) 'Intercultural public intellectual engagement' in Fethi Mansouri (ed) Interculturalism at the Crossroads: Comparative perspectives on concepts, policies and practice, United Nations Educational, Scientific and Cultural Organization, France, pp. 83-102.

2 Google defines a sophist as: 'a paid teacher of philosophy and rhetoric in Greece in the Classical and Hellenistic periods, associated in popular thought with moral scepticism and specious reasoning'.

*Corresponding author: Tariq Modood, the University of Bristol, E-mail: T.Modood@bristol.ac.uk 
While both these kinds of oral exchanges have lived on and are central to the disciplines of philosophy and political theory-as in the " $\mathrm{Q}$ and $\mathrm{A}$ " after a lecture, at a seminar or tutorial-the dialogue as a literary form is the exception rather than the norm in any academic discipline. While the oral exchanges, principally of the adversarial kind, do have a lively presence in certain democracies, not to mention in courts of law, the dominant mode of reasoning together that modern theorists have conceived as appropriate for the most fundamental questions of political life is altogether different. The dominant tradition in modern western political theory is that of the "social contract". When theorists like Thomas Hobbes, John Locke or Jacques Rousseau pose questions about why polities exist and what gives rulers the right to rule, they assume that the question is posed of individuals who can be hypothesised to give their free consent. This assumes that the individuals know what they want. They negotiate amongst themselves to get the best deal for themselves or for all parties, yet they reason about the founding of states and coercive laws on the basis of pre-existing desires and preferences, which are already known to them. There is, however, one line of continuity with Socrates. While it is assumed that individuals will vary in their desires, it is further assumed that there is a single truth, a single set of principles or correct answer to be discovered by Reason.

While Hobbes postulated that all would rationally choose to subject themselves to absolute authority because the alternative, the "state of nature", was permanent insecurity and constant likelihood of death (Hobbes 1968 [1651]). Locke thought all persons had certain natural rights that could not be overridden, and so individuals would only give their consent to be ruled by a state which had a mechanism for self-limiting its power by, for example, having an independent judiciary to check that the government respected the rights of each individual (Locke 1966 [1690]). Rousseau took this idea of individuals contracting to obey a common authority further by conceiving it as not just a foundational act, but as a process of democratic law making by citizens. For him, this meant that that the conditions for the emergence of law in an assembly had to be of a particular kind. Above all, they should be such that the citizens should not be thinking in terms of their personal desires or gain, their class interests or political party membership, but should think in terms of what was best for the republic. Only then would their "general will", as opposed to a collection of personal wills, manifest itself (Rousseau 1920 [1762]).

John Rawls is the most important recent theorist in this tradition. He too looks to found politics and social justice on what free, rational individuals would collectively agree to after discussion. Like Rousseau, Rawls thinks that the conditions or circumstances in which such dialogue takes place are critical. The discussants should be able to focus on what is good for individuals in general, or to put it differently, what all individuals would want after reflection, not on what individuals like themselves would want. They must think selflessly-literally. Rawls designs a thought experiment, the centrepiece of which is what he calls "the Veil of Ignorance" (Rawls 1971). For the deliberation of individuals to lead to the discovery of social justice or 'fair terms of social cooperation' (Rawls 1985, p. 232) they must be made ignorant-stripped of their specific identities such as their gender, their class, their nationality, culture, religion and so on. So none of the reasoners knows, for example, whether they are rich or poor, black or white, Christian or Muslim and so on. So no one will risk favouring laws and policies that unduly favour a particular class, race, or religion so that when, at the end of the deliberation, the Veil is lifted and they (re)learn who they are, it turns out they are not of the group they favoured.

Rawls' claim is, then, that the principles of social justice can only be worked out by individuals, intellectuals, law-makers, benign governments and so on, to the extent that they approximate being selfless or identity-less reasoners. That, however, means that dialogue among such individuals is not necessary because, stripped of all their differences, such reasoners are identical. One reasoner can, in theory, come up with the just solution without there having to be a dialogue among all the citizens. Moreover, behind the Veil of Ignorance, the debate makes no difference concerning what is valuable in the product of the debate. The product-the principles that a diverse society should live by-are not influenced by who is or is not included in the debate, and so they remain the same however the debate goes. That is to say, they are not influenced by the debate and could indeed have been known without any dialogue having taken place. More precisely, they are known by reason not by dialogue or by who participates in the dialogue. 


\section{Dialogue as used by Multiculturalists}

This is not, however, how multiculturalists have approached political theory. Dialogue, rather than abstract reasoning by a sole reasoner or identical identity-less individuals, has motivated multiculturalists. They assume that the context for politics is already thoroughly imbued with dominant ways of thinking and doing-with cultural orientations such as national history and language, with religious and/or secular perspectives, with institutional norms and so on-and that these contextual factors cannot be abstracted out so as to identify a set of culture--free problems. Moreover, the relationship between the relevant parties is likely to involve domination-subordination, or inclusion-exclusion and that the weaker or newer party is likely to lack recognition or be misrecognised (Taylor 1994). Dialogue rather than identity-less reasoning will be relevant here for at least three reasons. Firstly, the solution to the problem, or the arriving of a principle by which to address the problem, needs an effort at cross-cultural understanding. It is not just a question of taking material interests into account, but a matter of (re)designing the shared public space and rules of conduct so diverse cultural commitments and needs are explicitly taken into account, so that the public space does not simply reflect the dominant culture, but is opened up to accommodate new or marginalised minorities. Secondly, this means that the solution is genuinely open. By this I do not mean that "anything goes". Rather, that the solution cannot be predicted in advance in the way that, say, the final step of a piece of mathematical reasoning can, of which we say the answer was there all along waiting to be discovered. The dialogue makes a difference: it contributes to a growth of understanding that genuinely is novel or additional to what was present before and the quality or character of the dialogue is dependent on the participants, not simply in terms of their power of reasoning but in terms of "where they are coming from", so that with different parties a different outcome would have been reached. Thirdly, the dialogue is important not just in discovering an outcome, but in building a relationship of trust, co-operation and ultimately of belonging together between parties to the dialogue. These three reasons makes the dialogue very different from the "behind the veil" reasoning of identity-less reasoners.

The multiculturalist political theorists I have in mind include Iris Young, who assisted people in understanding themselves as oppressed, discovering themselves in collective identities such as black or gay, and to thus develop a liberatory identity and group politics and use it to engage with other groups to institute a new form of democratic politics (Young 1990). Charles Taylor's idea of a dialogical ethics and politics based on "recognising" those whose distinct cultural identities have been dismissed or held in contempt-such as the identities of African-Americans in the USA or Francophone Quebecers in Canadais also an example (Taylor 1994). Interestingly, in his more recent work, Taylor relates his approach to diversity to a Rawlsian idea, that of 'an overlapping consensus' (Rawls 1987; Taylor 2009). ${ }^{3}$ For Rawls, this referred to the body of laws and policies that those with different religious and cultural perspectives could all agree on by focusing on politics rather than their full set of religious and value commitments. Taylor rejects the idea of the identity-less self (sometimes referred to as 'the unencumbered self') and abstract reasoning as the method for arriving at a consensus. He borrows and adapts 'overlapping consensus', but makes the process of arriving at it much more expansive and dynamic so that it in fact is best understood as consensus building; something not given but to be worked at, including through new interpretations of actors' points of views, one of the things that one might expect from a dialogue (Taylor 2009). James Tully has continually emphasised that cooperation under conditions of deep diversity or 'multiplicity' requires a 'multilogue' (Tully 1995), and has proposed the idea of 'public philosophy', the questioning of society's dominant assumptions to expose their contingency-their lack of necessity-and so open the way to identifying other possible ways of thinking and living (Tully 2008). Bhikhu Parekh explicitly makes intercultural dialogue central to his conception of multiculturalism. His interventions in relation to The Satanic Verses Affair, in which he argued against a freedom-of-speech absolutism and argued that angry Muslims must be given a sympathetic hearing, are exemplary (Parekh 1989). ${ }^{4}$ While fully recognising that

3 At this stage Rawls had moved away from the Veil of Ignorance methodology of his most famous work (Rawls 1971) as described earlier.

4 When published in March 1989, five weeks after Khomeini's infamous fatwa, it was way ahead of the debate to which it 
in such public controversies the majority dominate public discourse, and often in a manner that is not conducive to dialogue or mutual learning, he argues that multiculturalism is not about allowing each minority to-live-as-it-wishes relativism (Parekh 2006). Rather, it is about ensuring that there is a genuine dialogue and that the minority is allowed to express its point of view. While such dialogues inevitably have a majoritarian or status quo starting point, because even while wanting to express unfamiliar sensibilities and bring in new arguments, minorities are primarily trying to persuade the majority. This often takes the form of a minority arguing that what it is seeking is not so different to what the majority, at one time or another, has sought for itself. In so arguing, the minority must justify itself by appealing to-even while seeking to modify-the existing 'operative public values' which structure public debate and what is thought to be legitimate or reasonable in that polity at the time (Parekh 2006, p. 267). ${ }^{5}$

For such multiculturalists, the principles of social justice are not known in advance or simply by reason, but are arrived at by conflict and learning, by dialogue and negotiation in circumstances of inequality and minority-claims making. Admittedly, in Rawls' methodology, there is a to-ing and fro-ing from principles and experience/particularities/context-what he calls 'reflective equilibrium' (Rawls 1971). But it can be done by an isolated reasoner or an assembly of identity-less, selfless reasoners, because at its best it is disinterested, selfless reasoning carried on far away from conflict. For the multiculturalists, the dialogue is claims based and contentious, and based on identity assertion (relative to other identities), not identity effacement. It seeks to get beyond-even if it never gets there-the conflict or challenge to which it gives rise by urging the recognition of the excluded, the inferiorised and the misrecognised, and by the formation of new, inclusive, hyphenated and multiple overlapping identities. The dialogue comes into being because of identity-based claims; it proceeds by recognising identities; and its goal, its teleology, is the construction of new identities and new relationships, which are not reducible to redistribution.

\section{Multiculturalism and Interculturalism}

The kind of public intellectual engagement or multiculturalist dialogue I am arguing for here needs to be contrasted with other conceptions of intercultural dialogue. It can, for example, be contrasted with a philosophical multiculturalism which is concerned to develop a frame in which different cultures and religions can come to an understanding of each other and, therefore, to a richer understanding of humanity. Taylor, for example, sees the ultimate frontier of the politics of recognition as being the development of sensibilities and ways of thinking that allow us to understand cultures radically different from our own and thereby evaluate their contribution to human civilisation (Taylor 1994). Taylor also he sees this frontier as far from contemporary capacities. Similarly, Parekh emphasises that the ultimate value of multiculturalism lies in cross-cultural and cross-civilisational understanding through which we simultaneously appreciate the varied ways to be human, whilst more profoundly understanding one's own distinctive location (Parekh 2000). While my own formulation of multiculturalism is built on a reading of Taylor and Parekh (among others), the philosophical views which I have just ascribed to them carry important and controversial philosophical theses, which I can leave to one side. For example, Taylor's suggestion that different cultures can be evaluated and ranked by and against each other. Or, Parekh's moral intersubjectivism: the view that values and morality, while grounded in a conception of human nature, ultimately have no foundations independent of reasoning selves (Parekh 2006, p. 128). These are debates that I do not need to enter. My interest and advocacy is confined to political multiculturalism. While Parekh and Taylor locate their political multiculturalism within a wider, philosophical multiculturalism, I am not locating political

contributed. Besides his own publications, Parekh used his office as part-time Deputy Director of the Commission for Racial Equality at the time to convene three workshops on the topic, the publications from which also considerably raised the level of intellectual engagement.

5 This also at least partly gives political multiculturalism the character of a bottoms-up mobilisation, paralleling other kinds of identity politics like feminism or gay pride, as I display in relation to Britain (Modood 2005). Bloemraad (2015, p. 11), however, has argued that that multicultural discourse and policy in Canada, Australia and Sweden was elite-driven. 
multiculturalism in anything bigger than itself, or more precisely, in nothing bigger than contemporary ideas of democratic citizenship and belonging (Modood 2013, pp. 60-61).

Relatedly, I leave to one side how what I am presenting as multiculturalist dialogue relates to identity groups at an international or global level, as in the idea of a "dialogue of civilizations". I will confine myself to an intranational context, and more specifically to liberal democratic contexts. Within such contexts there has been a reaction to multiculturalism that relates to the question of dialogue, specifically to intercultural or interfaith dialogue. Multiculturalism has been criticised at many levels and across the political and intellectual spectrums, but I am referring to one specific position that goes under the name of "interculturalism". To be more precise, there are at least two reactions that use the same self-label. One reaction is specific to Quebec and is very much connected to Quebec nationalism (Meer and Modood 2012; Modood 2014). This interculturalism, however, is not a rejection of dialogical or identity politics. On the contrary, it conceives of the multiculturalism of Canadian federal government as not sufficiently dialogical, but as being too based on justiciable individual rights and judges rather than on political dialogue (Gagnon and Iacovino 2006). The other interculturalism is associated with the Council of Europe (2008) and UNESCO (2008). These bodies have produced a critique of multiculturalism, which, with Nasar Meer, I have examined and rebutted elsewhere (Meer \& Modood 2012). ${ }^{6}$ Our argument was that this interculturalist critique is of a caricature without any significant reference to the views of any multiculturalist authors, theorists and advocates, or even to policies advanced in the name of multiculturalism, say in the UK, Canada, USA or Australia. It simply associated multiculturalism with separatism, ghettoisation and anti-integration (Meer \& Modood 2012; see Meer, Modood \& Zapata-Barrera 2016 for a multisided debate). My point of interest here is on only one aspect of the interculturalist critique and the corresponding positive recommendation. This is the argument that multiculturalists have been too focused on general public discourses, especially at a macro national level, whereas the real work of social acceptance, equality and living in diversity is at the level of everyday life in one's neighbourhood, school, workplace and so on (Loobuyck 2016). At the level of the latter, people rub along without major value conflicts, but nevertheless, intercultural encounters rather than avoidance of contact is essential for a multicultural society and so it is at these micro levels that the techniques for intercultural dialogue needs to be learnt and practiced (Wise \& Velayutham, 2009). Multiculturalism, it is alleged, is too focused on the macro and the conflictual, and dialogue should be redirected to the micro and the cooperative. ${ }^{7}$ My response to this critique is to accept it as a correction to an exclusively macro and political focus but to reject it as presenting an either-or choice. One can welcome the interculturalists' focus on microrelations, but this does not require abandoning the idea of dialogue at the level of political controversies and public discourses. Groups and intergroup problems exist in society and cannot be simply handled at a micro level of contact, interaction and sociability. ${ }^{8}$

\footnotetext{
6 Oddly enough, while the cited article has been viewed and cited in numbers that are satisfying to its authors, and the article was published together with four responses and a rejoinder, it is not too unusual for the article, which engages with the interculturalist critique of multiculturalism, to be read as an endorsement of that critique, when it is of course a multiculturalist riposte to that critique.

7 In its British version the critique is less likely to be expressed in terms of 'interculturalism' and more in terms of a positive focus on 'multiculture' or 'conviviality' or 'everyday multiculturalism'. I have subsumed it under what I refer to as 'cosmopolitanism'. Under 'cosmopolitanism' I bring together the interculturalist emphasis on cultural encounters and everyday interaction in localities, schools, clubs, public spaces, the multiple and fluid character of identity, the emphasis on the transnational and on globalisation and the 'problematising' of the national (Modood 2012).

8 Loobuyck too uses the macro-micro distinction to distinguish between interculturalism and multiculturalism, but he conflates it with a state-civil society distinction (Loobuyck 2016, p. 230) and does not see that multiculturalism is not confined to the state and extends to citizen-to-citizen relations (Modood 2007/2013: chapter 6). Contrary to another distinction he makes, multiculturalism is not just about justice and neglects the importance of belonging: on the contrary, belonging is more central to multicultural nationalism than either the liberal goal of furthering autonomy or the social democratic means of redistribution of resources. Stokke and Lybaek 2016 offer a better combining of intercultural dialogue with the kind of political multiculturalism that I advocate, but they perhaps overstate the separation of multiculturalism at the level of political critique and mobilisation from multiculturalism at the level of state. In my view, multiculturalists need to draw the state into public dialogues, not define it as something beyond the scope of the reach of dialogue and learning.
} 


\section{Public Intellectual Engagement}

The kind of macro-level dialogue that I am speaking of can also be understood as a form of public intellectual engagement. One of the best known statements on the nature of public intellectuals in recent times is that by Edward Said (Said 1996). Following Gramsci, he drew a contrast between traditional intellectuals, who here we might understand as academics, and 'organic intellectuals', namely those who serve particular organisations, such as journalists, or lobby for particular interests for a fee, or have an expertise, such as an economist or a scientist working for a government (ibid., pp. 4, 13). Derived from a characterisation by Benda, Said writes of a third kind of intellectual, 'of the intellectual as a being set apart' (ibid., p. 8), angry and oppositional, a critic of all worldly powers. They marry the academic's commitment to intellectual values, but combine it with a critique of injustice, which is aimed, not just at fellow specialists, but at as wide a public audience as they can manage. I can offer my understanding of public intellectual engagement by relating to Said's idea of a public intellectual, which I find too one-sided and painted too starkly.

An example of the one-sidedness I mean is the detachment from society that Said attributes to public intellectuals. He argues that their aim is to uphold universal 'standards of truth about human misery and oppression ... despite the individual intellectual's party affiliation, national background, and primeval loyalties' (ibid., p. xii). Of course this kind of integrity is what one requires not just from public intellectuals but from all professionals, such as academics, doctors, judges, engineers and so on. It is neither distinctive of public intellectuals, nor does it mean that those with such responsibilities have to be less members of their society; that they share less understanding and concerns with their co-ethnic, co-religionists or co-nationals, or do not care about the well-being of their groups (including protesting when they think injustice is being done by their groups). Yet, Said describes public intellectuals as, indeed exhorts them to be, 'outsiders and exiles' (ibid., p.51) and admiringly quotes Adorno: 'It is part of morality not to be at home in one's home' (ibid., p. 57; italics in original). Said notes that '[b]ecause the exile sees things both in terms of what has been left behind and what is actual here and now, there is a double perspective that never sees things in isolation' (ibid., p. 60). Thus, despite presenting a self-image of the intellectual as standing outside or above the society with which s/he is engaging, Said recognises there actually has to be one (or more typically, multiple) commitment to a people(s) or concrete institutions and practices, not just to abstract principles like Truth or Justice or Humanity. My point is that commitments to groups, people, causes, institutions, one's country, and so on are not incidental to an engaged public intellectual or a nuisance it would be best did not exist. They are as essential to the public intellectual as the commitment to intellectual integrity. The public intellectual has to care about a people, a place or a cause, and not just about being an intellectual (brought out nicely in relation to George Orwell and Albert Camus in Walzer 2002). The public intellectual has to have a home, but this commitment must not be blind or incompatible with an equally strong commitment to intellectuality. Just as, of course, there must not be a blind commitment to certain intellectual points of view and theories, including those which have the prefix of "critical"; a prefix that seems to some to be a badge of adherence rather than something to deconstruct. The public intellectual endeavour is to engage in and lead the moral, ethical and political conversation that any society has with itself, and while some "outsider" features can offer some epistemological advantages (and no doubt some blind spots), one needs to be part of the society that one seeks to engage.

Said cites the African-Americans James Baldwin and Malcolm X as exemplars of public intellectuals (Said 1996, p. xvii). Yet they were individuals who knew which side they were on. They were outsiders to certain structures of power but not outsiders to groups, to belonging and commitment to the well-being of the groups to which they (thought) they belonged. It is most unlikely that they endorsed Said's motto of 'Never solidarity before criticism' (ibid., p. 32). In Said's own case there was a passionate lifelong commitment to the Palestinian people. Moreover, when it comes to multiculturalist public intellectuals, they are likely to belong to more than one group, and so are unlikely to be either wholly insiders or outsiders; again something that describes Said as an eminent American. The public intellectual, then, has to negotiate critical outsiderness and epistemological insiderness and belonging, solidarity and rootedness. S/he does not need to give up entirely on her social roots; indeed, to do so is to risk losing an important understanding and sympathy for her group or society as well as trust and standing with the group and/or society. So, it is 
not to cultivate blind loyalty, nor is it to go into exile; it is much better to develop multiple belongings and possibilities of dialogue rather than exile or aloofness from the concerns of one's group or society.

A similar one-sidedness characterises Said's distancing of public intellectuality from 'specialisation' (ibid., p. 76) and 'expertise' (ibid., p. 77), overlooking that a public intellectual has to be in one or some intellectual discipline(s). He argues that '[t]he particular threat to the intellectual today ... [is] an attitude that I will call professionalism' (ibid., p. 73), which he describes as treating intellectual work as just a job, on a nine-to-five basis, the demotion of an intellectual vocation to what today is likely to be called "work-life balance". Said also worries about intellectuals seeking acceptance, prestige and honours (ibid., pp. 100-1). I agree that some university institutional cultures-such as that of Britain, say, during 19902010-encouraged a narrow scholasticism, typified by the high esteem bestowed on disciplinary jargons and low esteem on clarity, but Said is too dismissive of expertise (Modood 2009). Much scientific expertise improves material living standards, public services and personal well-being. It is about engaging with the pressing needs of individuals and communities, such as seeking a cure for cancer, reducing world poverty or contributing to the advancement of "the knowledge society" with a view to improving regional and national productivity and promoting technological innovation. We may agree with Said, however, that such activity is not public intellectual engagement, which is about an intellectual speaking in their own voice to a public, not about research teams, new techniques and purely material concerns. And as for an intellectual not seeking honours, yes, that can't be the primary motive, but it is the case that there is-and should be-honour and recognition, and social status in public intellectual engagement. It is odd that Said, who received much such acclaim (including being chosen by the BBC to deliver the prestigious Reith Lectures, in which he presented the views I am discussing), should fail to mention it. A better understanding of how the professional, the personal, and what one might call honourable ambition interplay, is captured in this description of public intellectuals as 'those who live with the tensions generated by the contrasting pulls of specialist focus and peer recognition, on the one hand, and on the other the risks and thrills associated with being known as someone who addresses a much wider range of publics on issues of general concern' (Kenny 2008, p. 7). Of course these different elements are not always in harmony, but it is not a betrayal of vocation to recognise the fact and the dangers of competing motives and purposes rather than to define public intellectuals in ascetic and purist terms.

Despite Said's tendency to sometimes express himself in a one-sided way, he also offers a more complex characterisation and is closer to the mark when he does so, for example:

'There is therefore this quite complicated mix between the private and the public worlds, my own history, values, writings and positions as they derive from my experiences, on the one hand, and on the other hand, how these enter into the social world where people debate and make decisions about war and freedom and justice' (Said 1996, p. 12).

Thereishoweveroneissueon which Idonotsimply think Said has a preference, albeitexercisedinconsistently, for one-sidedness, but where our views collide. In earlier talking of Parekh as a multiculturalist public intellectual, I evidenced his interventions in relation to the crisis around Salman Rushdie's novel, The Satanic Verses. It happens that Said too refers to this crisis and states that to have failed to have defended this novel is 'to betray the intellectual's calling' (ibid., p.89). This is because 'uncompromising freedom of opinion and expression is the secular intellectual's main bastion' (ibid., p.89). In addition to what I have already said in relation to Parekh, in the interview below I give my own reasons for my own intervention in this crisis and so will not add anything more here. It may be that by "secular", Said does not mean nonreligious but as someone who does not have a 'belief in a political god' (ibid., p. 109) or 'a total dogmatic system' (ibid., p. 113). If so, I share that view and have warned of 'the danger of ideology' in discussions of multiculturalism (Said 2013, pp. 118-122). I suspect, however, that in at least one respect I take the freedom owed to public intellectuals further than Said, who so passionately defines the latter in anti-establishment and anti-national terms. Michael Burawoy, who initiated a major, international debate about the nature of public sociology, offered the same kind of political restrictedness, arguing that it 'defends the interests of humanity', which he interpreted to mean standing up for civil society against the market and the state (Burawoy 2005, p. 24). My colleague, Gregor McLennan, has added that if one can impose political tasks 
on sociology then his own list includes resistance to 'the encroachments of religiosity' (McLennan 2007, p. 859). In contrast, I think a public intellectual must be politically free to be left-wing, right-wing, centrist, religious, secular and so on-and of course to argue for his point of view by attending to other, especially dissenting voices, and respond to objections and critiques. Public intellectual engagement is of course political, not neutral, but it is a dialogue or a multilogue of complementary and contending intellectualpolitical positions and one cannot appropriate a whole discipline such as sociology or political theory for one's own normative position or against a colleague's (as Burawoy 2005 also, if inconsistently, argues). Or, as Hashemi argues, by juxtaposing the theorist of the Iranian Revolution, Ali Shariati, with Burawoy, 'public sociology can work as a frame of debate about the priority of each battlefield. Otherwise, it can be easily turned into a target for the criticism of those who do not share the interest in Burawoy's preferred struggle' (Hashemi 2016). The field outside the academy that public intellectuals are committed to is not civil society but the home of "the public", which we may call "the public sphere" following this excellent quote from Andrew Gamble which sums up in what way intellectuals are public or political:

The political theorists of multiculturalism such as Bhikhu Parekh ... have been active participants in politics in the sense that they seek to advance the political education of citizens, by articulating choices, framing questions, offering alternatives, and challenging orthodoxies and entrenched attitudes. They address themselves to the public, not to [just] coteries of experts, or office holders. They are essential builders of the public sphere (Gamble 2015, p. 297).

One of the ways, then, that intellectuals can contribute to societal dialogues is through what I will call "public intellectual engagement". As an exemplification of what I have in mind as an aspiration and in relation to multiculturalism, I offer in Part II the interview I gave to Simon Thompson (Modood 2016a). It refers to my own engagement with some of the challenges that the presence of British Muslims as British citizens creates for British public culture and the national citizenship. In relation to this theme, I have already mentioned Bhikhu Parekh above and my appreciation of him as an outstanding British public intellectual. ${ }^{9}$

\section{Part II : Tariq Modood: On being a public intellectual, a Muslim and a multiculturalist ${ }^{10}$}

\subsection{Interview by Simon Thompson}

\section{What does it mean to be a public intellectual?}

Intellectual or academic life is usually organised in disciplines, and intellectuals' questions come out of those disciplines. But in public intellectual engagement the question does not primarily come out of a discipline. It comes from the public. It concerns our relations with each other as members of a society and especially as citizens of a polity. A public intellectual is a concerned citizen who accepts responsibility for their society and brings to its understanding insights of their discipline.

Most of what salaried academics do is contribute to their disciplinary community or to a broader academic community. So, a political theorist may say, 'Hannah Arendt was engaged with this question. This is a question that is still alive and her thought on this is strangely lucid. I want to revisit it and perhaps recover neglected aspects of it'. These questions all arise organically from thinking about Hannah Arendt.

9 This is nicely brought out in his conversations with Ramin Jahanbegloo in which his review of the principal themes of his opus display how an engagement with contemporary politics is a guiding thread (Parekh \& Jahanbegloo 2011).

10 A longer version of this interview was originally given and recorded in March 2015 and a considerably shortened and edited version appeared in the journal Renewal in its April 2016 issue (Modood 2016a) and is reproduced here with kind permission of the editors of Renewal. 
But we also at times think about questions that don't just arise from the discipline. So, for example, we think about the relationship between religious identity and political equality. Is there any relation? Does political equality simply mean we are not interested in anybody's religious identity? We simply don't suppress or promote any such identities? Sounds plausible. But then if we think about it we realise that in fact, some people's religious identity tells them to have an ethical orientation which is clearly social and political-to do with questions like what kind of economic relations to have or not have, to be hospitable to refugees or not. Whereas for other people their religious identity is an entirely private matter.

So if political equality means merely ignoring religious identities, we are favouring religious identities that are purely private, and not treating all religious identities equally. We're preferring a particular kind of religious identity. So now we are not just talking about, say, Hannah Arendt's ideas. We're thinking about our existing political arrangements in light of the claims that some Muslims or some Christians or, for that matter, some "new atheists" are making about political life and equality. We are engaged in public questions. But we are still drawing on academic conversations, academic tools, academic perspectives. ${ }^{11}$

Do you think we've resolved this question-about how to square equality for all religious identities with political equality-in Britain?

I think we have entered a period where we are rethinking the place of religion in relation to equality and the public sphere. But there's a deep antipathy to treating religious identities on a par with others. A good measure of this is how in the Labour Party or in a major trade union there can be a women's section, an LGBT section, a black or ethnic minorities section, but we can all imagine the consternation if and when Muslims ask for a Muslim or a religious minorities section!

Should all intellectuals or academics be public intellectuals?

Intellectual life, like society, has a division of labour. I'm not saying: 'all academics or sociologists or political theorists must engage in intellectual activity of just one kind.' The pursuit of knowledge for its own sake is a good, though it's not the only good we should be concerned with. We need a certain amount of publically supported fundamental or "blue skies" or pure academic research, because who knows what will come from it? Even the publically engaged intellectual working on political theory will still get a lot of value from the person who says 'I really want to understand Arendt.'

Public engagement is desirable rather than essential for individual academics. But when it comes to the collective-a department of politics or a school of sociology-I think it is essential for at least some of its members to be engaged. And what I mean by desirable is not simply "optional”; public engagement is something that should be pursued if possible.

Do you see yourself as bringing a specifically Muslim voice to public debate?

To answer this we need to go back to the Rushdie affair. The Rushdie affair was a pivotal intellectual and biographical moment for me, because in some ways I came to be a Muslim at that time. It would have been quite straightforward for me to walk away from all these angry, aggressive Muslims and simply say: they have nothing to do with me. But I thought instead: these people are something to do with me. I was working in racial equality and community relations, I had a sense of belonging, solidarity, with a community of suffering. I was aware of and proud of my Pakistani roots. I thought of myself as British Asian, so to extend that to think of myself as a British Asian Muslim didn't seem such a leap. But it wasn't obvious either. I knew other British Asians who didn't want to have anything to do with these "fundamentalists". I felt I needed to address Muslims as much as I needed to address the wider public, and I needed to address them in a way that both exhibited identification and solidarity with them and said: this is where I stand and this is where we should stand-and we should distinguish ourselves from some other Muslim positions. So it was a critical stance, but I was expressing it as a Muslim. ${ }^{12}$

11 In an earlier interview I give more content to the idea of a public intellectual by reference to Bhikhu Parekh and Stuart Hall, who have inspired me and exemplify two different kinds of public intellectuals: the reformer and the critic respectively; see D. O. Martinez (2013), 'Intellectual biography, empirical sociology and normative political theory: An interview with Tariq Modood', Journal of Intercultural Studies, 34(6).

12 Examples of my public or journalistic interventions in relation to the Rushdie Affair are collected in Modood 1992, pp. 69-87. 
My biography, or my social location, as a brown Brit of Pakistani origins and Muslim background, is very present in my work-both in the questions I am engaged with, and also to some extent the answers. But I don't think of myself as simply speaking as a Muslim. When I speak, I speak as a multiculturalist above all. This is the intellectual commitment that I bring to public debate.

Should public intellectuals stand up for the marginalised or dispossessed?

I don't accept the argument that the role of intellectuals is to always support the weaker party. We should all attend to the state of the weaker party. But that is an issue of justice and fairness, it's not especially to do with political theory or sociology or being an intellectual.

The answer to your question comes back again to the Rushdie affair. At that time, there were at least two prominent things motivating me. Concern for the well-being of British society. And concern for the well-being of British Muslims as a particular part of British society. I was trying to follow these two deep personal commitments equally. It wasn't just Muslims and Salman Rushdie who were affected. British society was affected by this incident-and, in fact, this set of issues is not confined to one country.

Some people might say about me: 'he doesn't care about Britain, he just wants to look after the Muslim constituency.' I personally have never thought along those lines. I have an abiding concern for the wellbeing of British society, which doesn't mean that British society sometimes doesn't misunderstand where its well-being lies. When I try and engage with a broader British public, I am trying to get people to think about what is really good for British society. What is consistent with its beliefs and long-term character? Because, of course, British society has to work and adapt to include in a fair and just way what we might call the new British. What I have been concerned about-in the Rushdie affair and after-has not been the well-being of Muslims per se, but the well-being of Muslims who are part of British society and whose future is part of British society. The well-being of these parties is entangled, and the conflictual parts of the entanglement have to be worked out so that the well-being of each becomes interdependent and, if you like, integrated.

Does sharing an identity mean sharing solidarity?

My biography gives me insights and a sensibility that others don't have. I don't claim to be especially empathetic, but I can say that I know certain things, having been brought up as a Muslim, having been an Asian in Britain since I was a child, and going to a very white, working-class school with a lot of racist and other kinds of bullying. I think this was the basis for my career. I could see that the way that British society was beginning to politically conceptualize the issues around race in the 1970s and 80s just did not fit with my own sense of who I was. And I felt that I was actually the norm in Asian communities and not the exception; for example, like most British Asians, I did not think I was black, nor, of course, white; nor did I define myself against Britishness but as making a new, distinctive claim on it. That gave me the basis for arguing against a kind of black-white racial dualism and towards ethnic pluralism-towards multicultural Britishness, where there are different ways of being British.

The emergence of religion as a live issue, in particular the assertion of Muslim identity, was actually a bit of a surprise to me. When I first heard about the Rushdie affair I thought, 'it's not right for Muslims to be getting so angry.' But being among Muslims made me realise that this really mattered to some Muslims, and they were unable to do what their sympathisers were asking them to do-which was basically to just forget about the novel entirely. I could see that these Muslims were headed for a confrontation, and this wasn't good for Muslims or for British society. And because I could identify with them I could understand: not because I'm particularly empathetic, as I say, but because I belong to a certain social world.

You said above that the issues raised by the Rushdie controversy are not confined to one country. Could you expand on that?

Comparable issues to do with Muslims protesting how their religion, especially the Prophet Muhammad, is portrayed arose with the Danish Cartoons Affair and more recently the cartoons in Charlie Hebdo. In each case, an important question has been to look beyond the horrific violence and murder and to ask how, in a multicultural society, groups of people such as Muslims or Jews or blacks should and should not be portrayed. We need incitement to hatred legislation, but I think in the main, these issues should be dealt with through 'censure not censor' (Modood 2006) ${ }^{13}$ We should handle the offensive portrayal

13 The symposium in which this piece appears in is a good example of an intercultural debate between liberal free-speech 
of racial and religious minorities through censuring rather than legal bans. When several prominent European newspapers and magazines republished the original Danish cartoons of Muhammad, no British newspaper or magazine did so, on the grounds that they were not in the business of giving gratuitous offence. This is the same British approach that unlike France and many European countries has not tried to make Holocaust denial a criminal offence but dealt with it through a culture of civility and censure.

Do you think that racism, and in particular Islamophobia, are growing problems in this country, and what can politics do to fight against this rise?

Most of the evidence suggests that racial discrimination, say in relation to jobs, persists. Ethnic minorities continue to make progress in terms of socio-economic mobility and participation in public life, but that's mainly because of the extra qualifications they achieve rather than because there is a level playing field. On the other hand, I think that racial prejudice is in relative decline if we look at the views of younger people compared to older people, and at friendship, dating, relationships, marriage and so on. Yet both in terms of employment and social life, suspicion of and hostility to Muslims continues to rise. Partly this is collective blame for jihadi terrorism but it's also an antipathy to publicly asserted religious identities. This "Muslim penalty" has to be much more publicly stated as a problem. Blanket condemnation of racism is not enough. We need positive national narratives which feature Muslims and Islam as aspects of what it is to be British. Politicians also need to work with Muslim communities to identify, isolate and defeat the processes leading to terrorism, rather than speak as if Muslims were the problem or that terrorism is a problem the Muslim community could solve on its own-or indeed that it could be solved without the full engagement of the Muslim communities, including conservative Muslims and critics of government foreign policies.

You said that you see yourself as a multiculturalist intellectual. Do you think multiculturalism is still the model we should be following in Britain?

Multiculturalism is the accommodation of minorities not just as individuals but as people sharing, promoting and remaking their group identities within a common citizenship and the rethinking of a national story. No doubt this has sometimes been expressed too simply, both theoretically and politically, so we must learn from critics emphasising community cohesion, or the fluidity and multiplicity of identities, or what is called "interculturalism". But these are really modifications of multiculturalism, not alternatives to it. This is clear as soon as you pose the question: what is it that anti-multiculturalist countries like France or Germany have achieved that Britain has failed to achieve? In fact, by virtually any measure you care to pick-discrimination and victimisation, social mobility, presence in and participation in public life, rethinking national identity in a more inclusive way, inter-ethnic friendships, interfaith dialogue and cooperation and so on-the position of non-European origin minorities in Britain is better than in most or all other European countries. So, to paraphrase Churchill, British multiculturalism may be the worst model, except for all the others. In the last few years I have been particularly sympathetic to voices on the centre-left (like Jon Cruddas) emphasising that the cultural identities and anxieties of the majority need to be part of a communitarian One Nation politics. I think that is right, but it is important that such a politics should not be cast as anti-multiculturalist but should include what might be called a critically evolving multiculturalism. ${ }^{14}$

\section{References}

Bloemraad, I 2015, 'Theorizing and analyzing citizenship in multicultural societies', The Sociological Quarterly, vol. 56, no. 4, pp. 591-606.

Burawoy, M 2005, 'For public sociology', American sociological review, vol. 70, no. 1, pp. 4-28.

Council of Europe 2008, 'Intercultural dialogue: living together as equals in dignity', White Paper, Committee of Ministers, Council of Europe, Strasbourg.

absolutists and liberal inclusivists or multiculturalists, including Erik Bleich, Joe Carens and Randall Hansen and Brendan O’Leary, and relates to my earlier reference to Edward Said on free speech.

14 Further reading: Modood (2016b), Modood (2013) and Meer, Modood and Zapata-Barrero (2016). 
Gagnon, AG \& lacovino, R 2006, Federalism, citizenship and Quebec, University of Toronto Press, Toronto.

Gamble, A 2015, 'Multiculturalism and the public sphere', in V Uberoi \& T Modood (eds), Multiculturalism rethought, Edinburgh University Press, Edinburgh, pp. 273-299.

Hashemi, M 2016, 'A post-secular reading of public sociology', Social Compass, vol. 63, no. 4, retrieved 5 October 2016, <http://scp.sagepub.com/content/early/2016/09/21/0037768616663983.full.pdf+html〉.

Hobbes, T 1968 (1651), Leviathan, CB Macpherson, (ed.), Penguin, London.

Kenny, M 2008, 'Britain's anti-intellectual intellectuals: thoughts on Stefan Collini’s “Absent Minds”, Political Studies Review, vol. 6, no. 1, pp. 1-13.

Locke, J 1966 (1690), Two treatises of civil government, Dent, London.

Loobuyck, P 2016, 'Toward an intercultural sense of belonging together: reflections on the theoretical and political level' in N Meer, T Modood \& R Zapata-Barrero (eds), Multiculturalism and interculturalism: debating the dividing lines, Edinburgh University Press, Edinburgh.

McLennan, G 2007, ‘Towards postsecular sociology?’, Sociology, vol. 41, no. 5, pp. 857-870.

Meer, N \& Modood, T 2012, 'How does interculturalism contrast with multiculturalism?', Journal of intercultural studies, vol. 33, no. 2, pp. 175-196.

Meer, N, Modood, T, \& Zapata-Barrero, R (eds) 2016, Multiculturalism and interculturalism: debating the dividing lines, Edinburgh University Press, Edinburgh.

Modood, T. (1992). Not easy being British: colour, culture and citizenship. Stoke-on Trent, UK: Runnymede Trust and Trentham.

2006, 'The liberal dilemma: integration or vilification?' International Migration, vol. 44, no. 5, pp. 4-7.

2009, 'Universities and public benefit', 100: A collection of words and images to mark the centenary of the University of

Bristol, University of Bristol, Bristol, pp. 245-247.

2013, Multiculturalism: A civic idea, 2nd edn, Polity Press, Cambridge.

2014, 'Multiculturalism, interculturalisms and the majority', Kohlberg Memorial Lecture, Journal of Moral Education, vol. 43, no. 3, pp. 302-315.

2016a, 'On Being A Public Intellectual, a Muslim and a Multiculturalist: Tariq Modood interviewed by Simon

Thompson', Renewal, 24(2): 90-95.

2016b 'What is Multiculturalism and what can it learn from Interculturalism?' in 'Interculturalism versus

Multiculturalism - The Cantle Modood Debate', Ethnicities, Online First.

Parekh, B 1989, 'Between holy text and moral void', New Statesman and Society, 24 March, pp. 29-33. 2006, Rethinking multiculturalism: cultural diversity and political theory, 2nd edn, Palgrave Macmillan, Basingstoke.

Parekh, B \& Jahanbegloo, R 2011, Talking Politics: Bhikhu Parekh in Conversation with Ramin Jahanbegloo, Oxford University Press, New Delhi.

Rawls, J 1971, A Theory of Justice, Harvard University Press, Harvard. 1985, 'Justice as fairness: political not metaphysical', Philosophy \& Public Affairs, pp. 223-251.

1987, 'The idea of an overlapping consensus', Oxford Journal of Legal Studies, vol. 7, no. 1, pp. 1-25.

Rousseau, JJ 1920, The social contract: and discourses, no. 660, JM Dent \& Sons, London, Toronto.

Said, EW 1996, Representations of the intellectual, London, Vintage.

Stokke, C. and Lybaek, L. (2016) ‘Combining Intercultural Dialogue and Critical Multiculturalism’, Ethnicities Online.

Taylor, C 1994, 'The politics of recognition', in A Gutmann (ed.), Multiculturalism: examining the politics of recognition, Princeton University Press, Princeton.

2009, 'Foreword: what is secularism?' in GB Levey \& T Modood (eds), Secularism, religion and multicultural citizenship, Cambridge University Press, Cambridge, pp. 216-42.

Tully, J 1995, Strange multiplicity: constitutionalism in an age of diversity, Cambridge University Press, Cambridge. 2008, Public philosophy in a new key, vol. 1, Cambridge University Press, Cambridge.

UNESCO 2008, Investing in cultural diversity and intercultural dialogue: world report on cultural diversity, UNESCO, Paris.

Walzer, M 2002, The company of critics: social criticism and political commitment in the twentieth century. Basic Books, New York.

Wise, A \& Velayutham, S (eds) 2009, Everyday multiculturalism, Palgrave Macmillan, Basingstoke.

Young, IM 1990, Justice and the politics of difference, Princeton University Press, Princeton. 